\title{
VÍTIMAS E VILÕES EM REALITY SHOWS NO BRASIL: REPRESENTAÇÕES E AVALIAÇÕES COM BASE EM EVIDÊNCIAS LÉXICO-GRAMATICAIS ${ }^{1}$
}

\section{Cristiane FUZER*}

- RESUMO: O objetivo deste trabalho é analisar, com base em ocorrências léxico-gramaticais e semântico-discursivas, representações construídas em artigos de opinião publicados em jornais brasileiros. Foram verificadas as funções léxico-gramaticais desempenhadas pelos atores sociais selecionados a partir da recorrência no corpus, bem como as marcas de avaliação para as representações identificadas. Para isso, foram utilizados pressupostos teóricos da Linguística Sistêmico-Funcional, combinando categorias do sistema de transitividade de Halliday e Matthiessen (2004), das formas de representação de atores sociais de Van Leeuwen (1997) e do sistema de avaliatividade de Martin e White (2005). Os resultados mostram que os atores sociais mais frequentes no discurso são o próprio articulista, o reality show, os participantes do programa e os telespectadores. Eles aparecem ora ativados, ora passivados, dependendo do contexto linguístico a que se relacionam. A presença de marcas linguísticas de julgamento e apreciação, muitas vezes acompanhadas de gradação, evidencia avaliações negativas para o reality show e seus agentes, ao passo que o uso de marcas de afeto sinaliza uma defesa dos participantes por parte da voz autoral. Assim como os brothers, telespectadores brasileiros são representados como vítimas do sistema capitalista vigente, que se faz presente nas dinâmicas dos reality shows.

- PALAVRAS-CHAVE: Gramática sistêmico-funcional. Transitividade. Representação. Avaliatividade. Contexto. Mídia.

\section{Introdução}

A mídia tem se apresentado como poderoso instrumento de influência sobre o sistema social. Em sua discussão sobre a mídia como uma ferramenta importante para que os cidadãos possam influenciar, por meio de opiniões, o sistema político, Pimenta (2007) observa que, na mídia, situações do mundo privado acabam se "encontrando" em contextos comuns, nos quais interpretações particulares de cada experiência se entrelaçam. A partir das observações de Scheufele (2000)

* UFSM - Universidade Federal de Santa Maria. Centro de Artes e Letras. Santa Maria - RS - Brasil. 97.105-900 crisfuzer@yahoo.com.br

1 Trabalho vinculado ao projeto "Gramática sistêmico-funcional da língua portuguesa para análise de representações sociais" (GAP/CAL 025406), com apoio FIPE/UFSM, e ao GRPesq "Linguagem como prática social". 
sobre a conversação política, pode-se dizer que a mídia alimenta a interação entre cidadãos mais informados e estimula a discussão sobre os mais diversos assuntos.

A formação da opinião de cada indivíduo acontece, de acordo com Pimenta (2007), num momento de fusão de informações e culmina na formação da opinião pública. Com base em seu repertório e em sua subjetividade, o indivíduo toma conhecimento de um fato por meio da mídia e discute o assunto com outras pessoas, participando de uma rede de influências discursivas que viabiliza e enriquece a formação da opinião. A autora afirma ser impossível mapear e medir tal rede. Entretanto, tendo por base as ideias de Dryzek (2004), que considera a esfera pública uma "constelação de discursos" formada por manifestações particulares, Pimenta (2007) destaca um meio que possibilita uma melhor compreensão desse processo: a linguagem.

É ao funcionamento da linguagem em textos que circulam na mídia que se detém o presente estudo. Os textos, produzidos no período de 2004 a 2011, são cinco artigos de opinião disponibilizados no "Observatório da Imprensa", site que aborda criticamente textos que circulam na mídia nacional. Dizem respeito a programas conhecidos como reality show, que há onze anos são exibidos em emissoras de televisão brasileiras e têm causado muita polêmica no país, tendo em vista a explicitação que é feita da vida íntima dos participantes.

O objetivo deste trabalho consiste em investigar quais elementos linguísticos são escolhidos pelos autores dos textos para manifestar representações e, por conseguinte, opiniões sobre práticas sociais que envolvem a mídia e seus atores sociais. Esse propósito articula-se ao projeto "Gramática Sistêmico-Funcional da língua portuguesa para análise de representações sociais" (GAP/CAL 025406), que se dedica ao estudo de mecanismos da língua portuguesa usados para representar indivíduos, grupos, acontecimentos e fenômenos em textos midiáticos.

O percurso teórico-metodológico adotado advém de teorias que constituem a Linguística Sistêmico-Funcional, por congregar aspectos léxico-gramaticais e semântico-discursivos da língua em uso num dado contexto social. Para alcançar o objetivo aqui proposto, são utilizadas categorias do sistema de transitividade, pelo qual se realizam significados ideacionais, e do sistema de modo e de modalidade, pelo qual se realizam significados interpessoais, conforme princípios da Gramática Sistêmico-Funcional, de Halliday e Matthiessen (2004), apresentados na seção "Significados ideacionais e interpessoais e suas realizações léxico-gramaticais." Para análise de aspectos semântico-discursivos, são considerados pressupostos do sistema de avaliatividade, de Martin eWhite (2005), descritos na seção "Recursos de avaliatividade". Esses sistemas, combinados a algumas categorias do inventário sócio-semântico de Van Leeuwen (1997), apresentadas na seção "Formas de representação de atores sociais", fornecem evidências para a verificação precisa de representações e avaliações nos textos. 
Por meio dessas ferramentas analíticas, identificam-se representações manifestadas para os atores sociais envolvidos no evento discursivo em questão e analisam-se marcas de avaliação para as representações identificadas. Desse modo, objetiva-se demonstrar como determinadas escolhas linguísticas concorrem para a formação e divulgação de opiniões em forma de textos na mídia.

\section{Significados ideacionais e interpessoais e suas realizações léxico- gramaticais}

Com o propósito de entender como a linguagem atua e como é limitada pelo contexto social em que é usada, a teoria sistêmico-funcional considera a função como uma "propriedade fundamental da própria linguagem." (HALLIDAY; HASAN, 1989, p.17). Duas das funções básicas da linguagem são: construir, interpretar e representar o mundo para os outros e para nós mesmos (metafunção ideacional), bem como construir e manter relações interpessoais e a ordem social que está por trás delas (metafunção interpessoal) (HALLIDAY; MATTHIESSEN, 2004).

Uma parte importante dessa ferramenta de construção de significados ideacionais e interpessoais é a gramática, "[...] um recurso para construir significado na forma de fraseado." (HALLIDAY; MATTHIESSEN, 1997, p.3). Essa relação intrínseca entre semântica e fraseado se materializa na léxico-gramática, cuja unidade básica de análise é a oração. Cada metafunção da linguagem se realiza por um sistema léxico-gramatical: a ideacional (experiencial) pelo sistema de transitividade, e a interpessoal pelo sistema de modo².

O sistema de transitividade é um recurso para interpretar um domínio específico das experiências dos indivíduos no fluxo dos acontecimentos. De acordo com Halliday e Matthiessen (1997, p.15), experiências exteriores e interiores são construídas e interpretadas em "[...] um conjunto limitado de domínios de significado que diferem de acordo com o processo e a natureza dos participantes envolvidos nesse processo." Há seis tipos de processos pelos quais o ser humano representa suas experiências, cada qual com seus participantes específicos, como resume o Quadro 1.

\footnotetext{
A apresentação de significados ideacionais e interpessoais como informações que podem ser compartilhadas com o interlocutor, em forma de texto, realiza-se pelo sistema de Tema, que materializa a terceira metafunção da linguagem: a textual (HALLIDAY; MATTHIESSEN, 2004).
} 
Quadro 1 - Tipos de processos e participantes.

\begin{tabular}{|c|c|c|c|}
\hline Tipos de processo & $\begin{array}{c}\text { Significado } \\
\text { da categoria }\end{array}$ & Exemplos de verbos & Participantes \\
\hline $\begin{array}{l}\text { Material } \\
\text { Transformativo } \\
\text { Criativo }\end{array}$ & $\begin{array}{l}\text { fazer } \\
\text { acontecer }\end{array}$ & $\begin{array}{l}\text { praticar, construir, } \\
\text { pagar, exercer, ocorrer. }\end{array}$ & $\begin{array}{l}\text { Ator } \\
\text { Meta } \\
\text { Escopo } \\
\text { Beneficiário } \\
\text { Atributo } \\
\end{array}$ \\
\hline $\begin{array}{l}\text { Mental } \\
\text { Perceptivo } \\
\text { Cognitivo } \\
\text { Emotivo } \\
\text { Desiderativo } \\
\end{array}$ & $\begin{array}{l}\text { perceber } \\
\text { pensar } \\
\text { sentir } \\
\text { desejar } \\
\end{array}$ & $\begin{array}{l}\text { perceber, ver, ouvir, } \\
\text { lembrar, pensar, saber, } \\
\text { gostar, odiar, amar, } \\
\text { querer }\end{array}$ & $\begin{array}{l}\text { Experienciador } \\
\text { Fenômeno }\end{array}$ \\
\hline $\begin{array}{l}\text { Relacional } \\
\text { Intensivo } \\
\text { Possessivo } \\
\text { Circunstancial }\end{array}$ & $\begin{array}{l}\text { caracterizar } \\
\text { identificar }\end{array}$ & $\begin{array}{l}\text { ser (cruel) } \\
\text { ser (o vencedor) } \\
\text { ter (dinheiro) } \\
\text { estar (no programa) }\end{array}$ & $\begin{array}{l}\text { Portador } \\
\text { Atributo } \\
\text { Identificado } \\
\text { Identificador }\end{array}$ \\
\hline Comportamental & comportar-se & $\begin{array}{l}\text { sorrir, chorar, dormir, } \\
\text { pular, golpear }\end{array}$ & $\begin{array}{l}\text { Comportante } \\
\text { Comportamento }\end{array}$ \\
\hline Verbal & Dizer & $\begin{array}{l}\text { dizer, perguntar, } \\
\text { responder, contar, } \\
\text { relatar, explicar }\end{array}$ & $\begin{array}{l}\text { Dizente } \\
\text { Verbiagem } \\
\text { Receptor } \\
\text { Alvo } \\
\end{array}$ \\
\hline Existencial & Existir & haver, existir & Existente \\
\hline
\end{tabular}

Fonte: Elaboração própria com base em Halliday e Matthiessen (2004).

Assim, a oração como representação se constitui de processo, participante(s) e, eventualmente, circunstâncias (localização, causa, frequência, ângulo, dentre outros). ${ }^{3}$

Ao analisar textos sob esse enfoque, é necessário considerar que os significados ideacionais não traduzem uma realidade pré-existente. Em vez disso, deve-se considerar que "[...] falantes e escritores constroem sua experiência de realidade como discurso." (MARTIN; ROSE, 2003, p.66). Focalizase o conteúdo de um discurso com base nestas questões: que tipos de atividades são empreendidos, como os participantes dessas atividades são descritos, como são classificados e do que fazem parte. Em outras palavras, a metafunção ideacional diz respeito ao modo como a experiência de "realidade" (material e

3 Uma introdução à Gramática Sistêmico-Funcional em língua portuguesa com sistematização das principais categorias léxico-gramaticais de cada metafunção da linguagem, exercícios e atividades de análise de textos encontra-se em Fuzer e Cabral (2010). 
simbólica) das pessoas é construída em seus discursos, com base nas escolhas que realizam no nível gramatical.

As representações das experiências construídas pela linguagem podem ser compartilhadas entre indivíduos, constituindo a metafunção interpessoal da linguagem, a qual se realiza pelo sistema de Modo. Por meio de orações declarativas, interrogativas e imperativas, realizam-se proposições (troca de informações) ou propostas (troca de bens e serviços). Esse sistema é simultâneo com o sistema de polaridade, que consiste na escolha entre orações positivas ou negativas (HALLIDAY; MATTHIESSEN, 2004). Entre os polos positivos e negativo, há graus intermediários pelos quais os indivíduos podem expressar suas opiniões. Esses graus constituem o sistema de modalidade, que está relacionado a proposições e propostas. Associada a proposições ocorre a modalização, que expressa graus de probabilidade ou usualidade; associada a propostas ocorre a modulação, que expressa graus de obrigação ou inclinação. Tanto a modalização quanto a modulação expressam-se por meio de recursos como verbos modais, adjuntos modais, grupos adverbais e expressões como "é possível", "é certo", "é necessário", "está disposto a", entre outras.

\section{Recursos de avaliatividade}

Derivada da metafunção interpessoal da linguagem, o sistema de avaliatividade, ${ }^{4}$ teorizado por Martin e White (2005), propõe-se a identificar, nos textos, elementos que realizam significados avaliativos, por meio dos quais o autor expressa pontos de vista positivos ou negativos, gradua a força ou o foco do que enuncia e negocia a intersubjetividade. Trata-se de um "[...] sistema de significados potenciais avaliativos disponíveis para uso." (VIAN JR., 2009, p.104). Nesse sistema, o posicionamento avaliativo pode ser atitudinal e dialógico.

A Atitude corresponde a um dos subsistemas da avaliatividade e, na categorização de Martin e White (2005), abrange três campos semânticos: afeto, julgamento e apreciação. O afeto corresponde a avaliações pautadas nos sentimentos do autor em relação a pessoas, coisas, objetos e acontecimentos (ALMEIDA, 2010). O julgamento diz respeito a avaliações do comportamento das pessoas em termos de moralidade, legalidade, capacidade e normalidade, determinados por aspectos de cultura, expectativas, pretensões e crenças

\footnotetext{
Essa é a tradução para appraisal que tem sido mais frequentemente usada por pesquisadores brasileiros na área de Linguística Sistêmico-Funcional (como se verifica em Vian Jr., Souza e Almeida (2010); Lima e Corôa (2010); Vian Jr. (2009)). Esse termo recobre melhor o sentido de appraisal, na teoria de Martin e White (2005), do que os termos "apreciação", que é o correspondente a appreciation, um dos três subsistemas de Atitude, e "valoração", que reduz o escopo envolvido na avaliação, já que ao valor agregam-se crenças, emoções, afeto, relações sociais, dentre outros aspectos (VIAN JR., 2009, p.101-102).
} 
individuais. A apreciação, por sua vez, corresponde a avaliações sobre objetos, artefatos, processos e fenômenos no que tange à estética (CABRAL, 2007). Recursos léxico-gramaticais que podem expressar avaliações no domínio da Atitude são: epítetos, atributos, circunstâncias, processos (comportamentais e mentais, principalmente) e adjuntos modais.

Ao avaliar atitudes, o autor pode, ao mesmo tempo, graduá-las considerando o seu envolvimento com os interlocutores. Assim, outros dois subsistemas são propostos por Martin e White (2005): Gradação e Engajamento. A Gradação diz respeito aos graus das avaliações em termos de força (intensificação e quantificação) e foco (acentuação ou amenização de uma perspectiva) e pode realizar-se por meio de mecanismos de repetição, prefixos e sufixos aumentativos e diminutivos, reiteração de itens de um mesmo campo semântico, determinados processos verbais e relacionais, elementos de comparação metafórica.

Por fim, o posicionamento dialógico diz respeito ao processo de interação, em que os enunciados estão sujeitos a reações e objeções dos interlocutores. Trata-se do subsistema denominado por Martin eWhite (2005) de Engajamento. Por meio de diferentes recursos de expansão ou contração dialógica, a voz autoral pode "levantar vozes e posições alternativas" ou, ao contrário, agir no sentido de "desafiar, dispersar ou restringir o escopo dessas posições ou vozes" (WHITE, 2004, p.194). Os recursos de expansão dialógica são supor e atribuir (reconhecer e distanciar), enquanto os de contração dialógica são refutar (negar e contrapor) e declarar (concordar, afirmar e endossar). Isso pode ser expresso por meio de processos verbais, circunstâncias de ângulo e uma variedade de estruturas lexicais.

A análise desses recursos semântico-discursivos realizados léxicogramaticalmente possibilita a identificação de atitudes e posicionamentos avaliativos nos textos inseridos em determinados contextos sociais. Outro aspecto ainda pode ser observado na análise do funcionamento da linguagem nos textos: as formas como atores sociais estão representados em termos sócio-semânticos, conforme descrito na subseção seguinte.

\section{Formas de representação de atores sociais}

Dependendo da sua história de vida, cada ator social atribui certa relevância a determinados temas, aspectos ou situações, constituindo representações de suas experiências. As representações, conforme mostram Halliday e Matthiessen (1999), constroem-se nas estruturas sintáticas e na organização semântica da língua. As palavras são usadas como instrumentos para alcançar determinados propósitos nas atividades humanas. A escolha de uma palavra no lugar de outra pode 
construir diferentes significações e, por conseguinte, diferentes representações de um objeto, fenômeno ou ator social.

Especificamente em relação aos atores sociais, Van Leeuwen (1997) propõe um inventário com diversas formas pelas quais eles podem ser representados no discurso. As representações podem incluir ou excluir atores sociais conforme seus interesses e propósitos em relação à audiência a que se dirigem. Assim como Halliday (2002), Van Leeuwen (1997) considera a gramática como um potencial de significados ("o que pode ser dito") em vez de um conjunto de regras ("o que deve ser dito").

As categorias fundamentais na proposta deVan Leeuwen (1997) são a exclusão e a inclusão, dentro das quais outras categorias são reconhecidas. A exclusão do ator social pode ser total (supressão) ou parcial (encobrimento). Isso pode ser feito por meio de apagamento do agente da passiva, uso de orações infinitivas que funcionam como um participante gramatical, nominalização e adjetivação. A inclusão do ator social pode ser realizada por meio de diversos mecanismos, tais como: ativação e passivação, generalização e especificação, personalização e impersonalização.

O ator social é ativado quando é representado como força ativa numa atividade; no nível léxico-gramatical, geralmente desempenha funções como Ator, Experienciador, Dizente, Comportante, Atribuidor. Por outro lado, é passivado quando é representado, submetendo-se à atividade ou sendo afetado por ela; nesse caso, é mais comum aparecer desempenhando funções de Meta, Fenômeno e Portador, ou integrando uma estrutura circunstancial ou uma expressão com ideia de posse (possessivação).

Quando referenciados de modo generalizado, os atores sociais são representados como classe. Elementos gramaticais caracterizadores da generalização são: plural sem artigo definido, singular com artigo definido e tempo presente sinalizando ações habituais ou universais. Quando especificados, os atores sociais podem aparecer individualizados por meio de dados identificadores, ou fazendo parte de um grupo de pessoas, por meio de marcas de pluralidade ou quantificação.

Os atores sociais podem, ainda, aparecer personalizados ou não. No caso de personalização, há duas subcategorias: indeterminação (por meio de pronomes indefinidos e outros recursos para anonimato) e diferenciação (por meio de nomes próprios, honoríficos, papéis participantes que denotam parentesco, cargo ou profissão). A impersonalização pode ocorrer por meio de outras duas subcategorias: abstração, quando o ator social é representado por uma qualidade (por meio de Atributos e circunstancialização), e objetivação, quando o ator social é representado por uma referência metonímica que 
indica somatização, autonomização do enunciado e referência a determinada instituição. ${ }^{5}$

\section{Diretrizes metodológicas}

Com base na fundamentação teórica descrita na seção anterior, mapeamos e analisamos recursos da língua portuguesa usados para manifestar representações e avaliações para atores sociais envolvidos num dado contexto midiático. O corpus de análise se constitui de cinco artigos de opinião publicados no período de 2004 a 2011 e divulgados no site do Observatório da Imprensa. Os textos versam sobre o mesmo assunto: reality shows, em especial o que é produzido por uma das maiores emissoras de canal aberto do Brasil.

A análise seguiu estes passos:

a) mapeamento dos atores sociais presentes nos textos por meio de leitura prévia, considerando-se recursos de referenciação como: elementos de reiteração, sinônimos, hiperônimos, hipônimos, expressões nominais definidas, expressões metafóricas, pronomes e elipses;

b) verificação da frequência de ocorrências dos atores sociais no discurso, por meio de quantificação dos seus elementos de referenciação, realizada com auxílio das ferramentas WordListe Concord do software WordSmith Tools 5.0 (SCOTT, 2011);

c) descrição das funções léxico-gramaticais desempenhadas pelos elementos linguísticos que fazem referência aos atores sociais com maior frequência no corpus, conforme categorias do sistema de transitividade, descritos na Gramática Sistêmico-Funcional de Halliday e Matthiessen (2004);

d) análise das formas de representação dos atores sociais com base nas categorias propostas por Van Leeuwen (1997);

e) classificação das ocorrências de avaliatividade e interpretação do posicionamento da voz autoral mediante os atores sociais representados.

Os textos selecionados para análise estão referidos por códigos, conforme o Quadro 2.

5 Uma sistematização mais detalhada das categorias sócio-semânticas de representação dos atores sociais e dos elementos léxico-gramaticais tipicamente usados para expressá-la é encontrada em Fuzer (2010). 


\section{Quadro 2 - Códigos identificadores dos textos \\ que constituem o corpus de análise}

\begin{tabular}{|c|l|l|}
\hline Cód. & Título do artigo & Fonte da publicação \\
\hline T1 & $\begin{array}{l}\text { A pedagogia do } \\
\text { grande irmão } \\
\text { platinado }\end{array}$ & $\begin{array}{l}\text { Elaine Tavares. Publicado em: 27 jan. 2011. Disponível em: } \\
\text { http://www.observatoriodaimprensa.com.br/artigos.asp? } \\
\text { cod=627TVQ001 }\end{array}$ \\
\hline T2 & $\begin{array}{l}\text { A longevidade } \\
\text { que espanta }\end{array}$ & $\begin{array}{l}\text { Cláudio Ferreira. Publicado em: 18 jan. 2011. Disponível em: } \\
\text { http://www.observatoriodaimprensa.com.br/artigos.asp? } \\
\text { cod=625TVQ003 }\end{array}$ \\
\hline T3 & $\begin{array}{l}\text { O corifeu do Big } \\
\text { Brother Brasil }\end{array}$ & $\begin{array}{l}\text { Robson Terra. Publicado em: 03 mar. 2009 Disponível em: } \\
\text { http://www.observatoriodaimprensa.com.br/artigos.asp? } \\
\text { cod=527TVO002 }\end{array}$ \\
\hline T4 & $\begin{array}{l}\text { Pão, circo e BBB } \\
\text { http://www.observatoriodaimprensa.com.br/artigos.asp? }\end{array}$ \\
\hline cod=375TVO003
\end{tabular}

Fonte: Elaboração própria.

\section{Análise e discussão dos resultados}

Os dados obtidos com o mapeamento dos atores sociais presentes nos textos e a verificação do número de ocorrências no corpus mostram que os atores sociais mais frequentes no discurso são o próprio articulista, o reality show, os participantes do programa e os telespectadores, referidos nos textos por diferentes itens lexicais e gramaticais, como mostramos a seguir.

Os articulistas aparecem incluídos por meio de elementos dêiticos, ora explicitados por formas pronominais ("eu", "mim", "me", "nós"), ora em elipse, mas sinalizados por desinências verbais (como em "penso", "li", "fiquei"), totalizando 32 ocorrências.

Referências ao reality show são as mais numerosas no corpus - 108 ocorrências no total - e aparecem sob diferentes recursos: repetição, hiperônimo ("programa"), nomeações ("Big Brother Brasil", "BBB", "Grande Irmão"), hipônimos ("apresentador", "produtores", "brothers"), expressões metafóricas ("o enlatado holandês", "zoológico humano") e metonímicas ("casa", "jogo", "prêmio", "paredão"). 
Os participantes do reality show são referidos explicitamente em 69 ocorrências por meio de repetições, hiperônimos ("pessoas", "indivíduos", "grupo", "atores", "ser humano", "candidatos", "concorrentes"), grupos nominais qualificadores ("heróis", "aproveitadores", "pobre", "subcelebridade", "sabotador", "irmãos", "confinados"), além de formas pronominais ("todos", "alguns", "outros", "eles") e elipses.

Os telespectadores do programa, por sua vez, são referidos 71 vezes. Houve apenas uma ocorrência do termo "telespectadores"; as demais referências foram feitas por meio de sinônimos ("público", "audiência", "espectadores"), hiperônimos ("pessoas", "gentes", "população", "sociedade", "brasileiros", "massa", "povo"), elementos dêiticos ("nós", "a gente", "nos", "nosso").

A seguir, apresentamos a análise das funções léxico-gramaticais desempenhadas por esses atores sociais, tendo por base categorias do sistema de transitividade (HALLIDAY; MATTHIESSEN, 2004), as quais associamos a categorias do sistema de avaliatividade (MARTIN; WHITE, 2005) e a formas de representação de atores sociais (VAN LEEUWEN, 1997).

Os articulistas aparecem ativados, principalmente, na função de Experienciador de processos mentais cognitivos que apontam para diferentes tipos de atividades, como leitura (excerto 1), observação (excertos 2 e 3), reflexão e análise (excertos 4 e 5).

(1) Outro dia (eu) li um artigo de alguém criticando o que chamava de pseudo-esquerda que fica falando mal do BBB, mas que também dá sua espiadinha. E também (EU) li outras coisas de pessoas falando sobre o quanto há de baixaria no "show de realidade" da Globo. (T1)

(2) E (eu) fui observar um pouco deste zoológico humano. (T1)

(3) $\mathbf{( E u ) ~ r e p a r e i ~ q u e , ~ n o ~ f i m ~ d a ~ A v e n i d a ~ C o m e r c i a l ~ N o r t e , ~ e m ~ T a g u a t i n g a , ~}$ tem um lava-jato chamado Big Brother 2. (T2)

(4) (Eu) Fiquei por aí a matutar. [...] (T1)

(5) Há algum tempo (eu) estava analisando a performance do apresentador do BBB. (T3)

Essas escolhas linguísticas evidenciam que os autores dos artigos em questão representam-se como leitores de textos alheios, de onde ficam sabendo as opiniões de outras pessoas sobre o assunto de que tratam em seus próprios textos. Desse modo, evidencia-se a ideia de que, para se emitir uma opinião própria, é preciso não só ter acesso a informações e opiniões de outrem, mas também observar as situações ao redor de si e estabelecer relações por meio de operações analíticas. 
A partir dessas atividades, processa-se a formação da opinião da voz autoral, manifestada por recursos de avaliatividade, como verbos modais (excertos 7 e 8) e processo mental emotivo (excerto 6).

(6) A mim me parece que a maior fonte de angústia do programa não é bem a crueldade de se dispor a viver num mundo sem rotina e numa casa de vidro, mas ser obrigado a conviver com indivíduos no sentido pleno da palavra. (T5)

(7) (EU) Penso que há outras formas de a gente se divertir [...]. (T1)

(8) O que me entristece é saber que essa pedagogia capitalista seguirá se fazendo todos os dias nas casas das gentes [...]. (T1)

O uso dos modalizadores "parece" e "penso" evidencia as impressões da voz autoral sobre a realidade analisada. Ao mesmo tempo, verifica-se um movimento de expansão dialógica, nos termos de Martin e White (2005), uma vez que os recursos de modalização abrem o discurso para outras possibilidades de opinião. Em (6), a expressão "a mim me parece" mostra a voz autoral na direção de uma das hipóteses sobre a fonte de angústia presente no reality show, abrindo espaço para opiniões diversas da hipótese eleita pelo articulista. Esse recurso de expansão dialógica também se verifica no excerto (7), em que "penso" introduz uma opinião do articulista acerca do reality show como forma de diversão: se "há outras formas de a gente divertir", conforme pensa o articulista, fica a sugestão para o leitor não fazer uso de reality show como um meio de diversão.

Em (8), o articulista, ao desempenhar a função de Experienciador do processo mental emotivo "entristece", mostra-se afetado emocionalmente pela consciência que tem da permanência da situação analisada. Essa escolha léxico-gramatical sinaliza também uma avaliação negativa da "pedagogia capitalista" observada no reality show, evidenciando uma opinião desfavorável da voz autoral aos métodos usados pelo programa.

Muitas vezes, os articulistas incluem-se entre os telespectadores do programa, ora na função de Ator, como em (9), Identificado, como em (10), e Experienciador, como em (11).

(9) (Nós) somos convidados a bisbilhotar a vida alheia logo após o horário nobre da TV. (T2)

(10) nós, (somos) o público. (T3)

(11) Ao (nós) observarmos o dia-dia da casa do BBB [...]. (T4)

Por meio dessas escolhas léxico-gramaticais, é construída uma identidade para as pessoas (incluindo o articulista) que assistem ao reality show: um público que observa o dia a dia dos participantes do programa, agindo como bisbilhoteiros ou mexeriqueiros. Especialmente em (9), a voz autoral avalia a atitude dos 
telespectadores, sinalizando um julgamento negativo. Por outro lado, essa atitude não é considerada espontânea, porque os telespectadores são "convidados" a praticá-la. O agente do processo "convidar" está apagado, recurso que, conforme Van Leeuwen (1997), coloca o responsável pelo convite em segundo plano nessa passagem do texto, ficando o foco voltado para os "bisbilhoteiros".

Dessa forma, além de representarem-se como pessoas que participam na posição de telespectadores do reality show, que leem para se informar, observam as situações e refletem sobre os acontecimentos, os articulistas, nos textos analisados, representam-se como agentes que julgam o próprio comportamento e o dos outros e pensam em alternativas para uma situação com a qual não concordam. Por reunirem todas essas experiências, estão em condições de manifestar e sustentar opiniões, as quais poderão, por conseguinte, vir a influenciar a formação de opinião de outros leitores sobre o assunto em discussão - nesse caso, reality shows.

A representação do reality show, por sua vez, se realiza ora por ativação, ora por passivação. É ativado, principalmente, nas funções de Portador, como em (12) e (13), e Ator, como em (14), (15) e (16).

(12) Reality shows são ótimos negócios, com custos mais baixos do que os de outros programas (novelas, séries) e rentabilidade muito maior. (T2)

(13) Cada vez mais esses programas são muito mais show do que reality. (T2)

(14) O Big Brother, assim, exerce esse papel de colocar sob os holofotes novas imagens que possam direcionar o comportamento dos jovens do País [...]. (T4)

(15) O programa dá, sim, vazão a aproveitadores de plantão [...]. (T4)

(16) o programa desperta uma das piores atividades da vida moderna: o voyeurismo [...]. (T5)

Nas orações relacionais atributivas (12) e (13), reality shows são caracterizados como um negócio lucrativo, porque têm baixo custo e alta rentabilidade (haja vista a audiência desse tipo de programa). O uso da pluralização permite representar esse tipo de programa de forma genérica, estendendo para outros programas do gênero os atributos mencionados.

Entre os reality shows genericamente representados, inclui-se o Big Brother Brasil, sobre o qual está o foco em grande parte dos textos analisados. Esse programa em particular é representado, na função de Ator, como uma ferramenta que se presta a três funções: dar visibilidade para pessoas que possam direcionar o comportamento dos jovens, como expresso em (14); beneficiar aproveitadores, como em (15); e despertar o voyeurismo, como em (16). 
Analisando-se os recursos de avaliatividade empregados nos excertos, verificam-se marcas de apreciação intensificadas por elementos de gradação, como em "ótimos negócios" (12) e "muito mais show" (13), por meio das quais a voz autoral avalia os reality shows em geral. Para avaliar o Big Brother são usadas marcas de julgamento, como "exerce esse papel de colocar sob os holofotes novas imagens" (14) e "dá, sim, vazão a aproveitadores de plantão" (15). O julgamento também aparece intensificado por meio de marcas de gradação, como em "uma das piores atividades da vida moderna" (16).

Por meio desses recursos semântico-discursivos, realizados léxicogramaticalmente, as representações construídas para o reality show são avaliadas sob dois pontos de vistas. Sob o ponto de vista econômico, a avaliação é positiva, porque se constitui num negócio lucrativo que beneficia apenas produtores e patrocinadores. Sob o ponto de vista sócio-educacional, no entanto, a avaliação é negativa, porque estimula a curiosidade mórbida e expõe imagens protagonizadas por aproveitadores que podem influenciar o comportamento dos jovens (nem sempre em direção a bons valores). As representações associadas a essas avaliações deixam pistas de quem são os reais beneficiados com a veiculação de reality shows na mídia, os quais estão encobertos nos excertos analisados por meio do apagamento da agência em nível léxico-gramatical. Em (12), por exemplo, quem é beneficiário dos lucros? A população que assiste certamente não é.

A antipatia dos autores em relação ao Big Brother é manifestada nos textos por meio de apreciações negativas, materializadas por uma série de Atributos constituintes de orações relacionais que estruturam definições para esse reality show no ponto de vista dos articulistas, como se verifica em (17) e (18).

(17) O show da Globo é uma violência explícita, cruel, nefanda, sinistra e miserável. É coisa ruim, malcheirosa. (T1)

(18) Há um programa chamado Big Brother Brasil [... e um Brasil do big brother. $\mathbf{O}$ primeiro é uma impiedosa experiência comparável em crueldade ao circo romano [...]. (T5)

Em outras passagens, o reality show aparece representado por passivação, quando desempenha funções de Fenômeno, como em (19), e de Circunstância de localização, como em (20).

(19) [...] fui observar um pouco deste zoológico humano [...]. (T1)

(20) Cada uma daquelas criaturas que ali está quebrando todas as regras da ética do bem viver é um pobre ser humano [...]. (T1) 
Essas escolhas léxico-gramaticais representam o programa não como agente, mas como um lugar onde seres humanos estão expostos à contemplação por outros seres humanos. Nesse lugar, quem age são as "criaturas" que quebram "todas as regras da ética e do bem viver". O reality show é representado, assim, como isento de responsabilidade sobre comportamentos antiéticos, já que é apenas um espaço onde esses comportamentos são praticados.

Os participantes do programa (os brothers), por sua vez, são ora ativados, ora passivados, dependendo do contexto em que aparecem. Na relação com os demais participantes do programa, verifica-se ativação, quando os brothers desempenham funções de Ator de processos concernentes ao jogo, como em (21), (22) e (23), e de Experienciador de processos mentais desiderativos concernentes a objetivos que os levam a participarem do reality show, como em (24) e (25).

(21) (o rapazinho) Precisava sabotar seus amigos. E o fez. Em nome do milhão. [...] na condição de um desgraçado que entrega seus colegas. (T1)

(22) [...] as intrigas diárias promovidas pelos participantes do programa. (T4)

(23) [...] os participantes do programa abriram mão dessa inviolabilidade (a vida privada) como valor. (T5)

(24) [...] todos se querem bonitos, atraentes, espertos, malandros, espirituosos e bem vestidos. (T5)

(25) (brothers) Querem pegar com as unhas a promessa que 0 sistema capitalista traz na sua pedagogia da sedução: 'Qualquer um pode neste mundo livre'. (T1)

Sabotar amigos, promover intrigas e prescindir do direito de privacidade fazem parte das regras do jogo, que oferece um prêmio milionário ao vencedor. Essas ações configuram-se em julgamentos expressos pela voz autoral, com marcas de avaliação negativa: "sabotar", "desgraçado", "intrigas", "abrir mão dessa inviolabilidade". Tais comportamentos, mencionados em (21), (22) e (23), não são particulares a um ou a outro brother, mas estendidos a todos que participam ou virão a participar do jogo, configurando uma representação por generalização, conforme Van Leeuwen (1997).

Essa generalização se verifica também em (24) e (25), quando os brothers, na função de Experienciador do processo mental desiderativo "querem", são representados como desejosos de atributos relacionados não só a aparência ("bonitos, atraentes, bem vestidos") e comportamento ("espertos, malandros, espirituosos"), mas também a poder ("pegar com as unhas a promessa" de que qualquer um pode). 
A disputa entre os participantes do programa é representada pela reciprocidade nas funções de Ator e Meta, ou seja, os brothers participam do processo como agentes e afetados simultaneamente, como ocorre em (26).

(26) [...] todos os membros do grupo têm o propósito explícito de derrubar ou tirar da 'casa' (o laboratório onde estão) todos os outros.

Esse excerto retrata o caráter competitivo imposto pelo jogo, em que os brothers, representados aqui também de forma genérica, derrubam e são derrubados, tiram da casa e são retirados, alternando-se nos papéis de algozes e de vítimas.

Essa alternância de papéis ativos e passivos não se verifica, todavia, na relação com os produtores do programa, tendo em vista que os brothers aparecem, na maioria das vezes, passivados, desempenhando, em várias ocorrências, funções de Receptor, como em (27) e (28), Beneficiário, como em (29), e Meta, como em (30) e (31).

(27) (Bial) Dá respostas grosseiras aos confinados sob o aval da desconstrução, da aproximação artificial, da brincadeira ou virtuose. (T3)

(28) E assim vai o "grande irmão" propondo maldades e violências aos pobres sujeitos [...]. (T1)

(29) (Bial) Vai doar uma "fazendona" ou dote de um milhão de reais para um pobre do país da anestesia. (T3)

(30) [...] é perverso demais o que os "inventores" fazem com aquelas tristes criaturas. (T1)

(31) Bial faz o escárnio dos confinados na jaula ou prisão de luxo. (T3)

Em (27) e (28), os brothers são representados como destinatários de respostas e propostas verbalizadas pelos produtores do programa e, em atendimento a tais propostas, como praticantes de maldades e de atos violentos durante o jogo. A voz autoral mostra-se penalizada em relação à condição dos brothers ao empregar a expressão "pobres sujeitos" como marca de afeto, no sentido dado por Martin e White (2005).

Em outro excerto, (29), "pobre" é usado polissemicamente, uma vez que pode remeter tanto à condição de penúria financeira do Beneficiário do processo "doar", quanto à condição de um coitado digno de lástima, que inspira compaixão.

Nos demais excertos citados, os brothers, na função de Meta, são afetados por processos que têm como agentes os "inventores" do programa, mais especificamente seu apresentador, Pedro Bial. Este é representado como o mentor ou porta-voz das propostas dirigidas aos jogadores. Nessas passagens, 
os brothers também são defendidos pela voz autoral, o que se verifica pelo uso da marca de afeto "tristes criaturas" em (30) e de marcas de julgamento que avaliam negativamente as atitudes dos produtores do programa, como "perverso demais" em (30) e "faz o escárnio" em (31).

A ironia, indicada pelo uso das aspas em "grande irmão", no excerto (28), também corrobora a construção de um posicionamento que condena as atitudes do reality show que, apesar do nome, não se comporta como irmão, mas como carrasco. Ou será que a representação social que se tem para "irmão" - como aquela pessoa a quem nos ligamos para um fim comum ou ajuda mútua ou a quem nos consideramos unidos por sentimentos de fraternidade, conforme define Houaiss (2009) - já não é mais a mesma? Estará o Big Brother construindo uma representação alternativa para "irmão"? Como isso é assunto para outro trabalho, voltemos aos brothers do reality show.

As análises mostram, portanto, que as funções léxico-gramaticais associadas às marcas de avaliatividade exemplificadas acima representam os brothers como vítimas. Essa representação é explicitada em (32) e metaforizada em (33) e (34).

(32) Não são eles [brothers] os "imorais". São vítimas. (T1)

(33) [...] os brothers são os cristãos novos entregues aos leões [...]. (T3)

(34) [...] o churrasqueiro que salpica e "assa" os aspirantes ao sucesso (T3)

Em (32), os participantes são identificados, na oração relacional, como "vítimas", sendo-lhes negada pela voz autoral a identidade "imorais". Como uma estratégia de ilustrar esse processo de vitimização, os brothers são, em (33), identificados com os "cristãos novos entregues aos leões", numa referência a um dos métodos usados por judeus e romanos, na antiguidade, para punir cristãos, que eram perseguidos por causa de sua fé. No caso dos brothers, são, de certa maneira, "punidos" por causa do sonho de se tornarem milionários. Da arena para a churrasqueira, em (34), é reforçado o discurso da vitimização, uma vez que os brothers, como Meta, são o churrasquinho ao gosto dos telespectadores.

Desse modo, nos artigos de opinião analisados, as pessoas que se submetem a participar de um reality show aparecem representadas, principalmente, como vítimas - ora dos produtores do programa e da emissora de televisão, ora do sistema capitalista, cuja "pedagogia" as leva a desejarem coisas que só o dinheiro pode dar. Tal pedagogia aparece representada em (35) e (36):

(35) [...] a promessa que o sistema capitalista traz na sua pedagogia da sedução: "Qualquer um pode neste mundo livre". 
(36) Trata-se da consolidação, via repetição, de uma pedagogia, típica do capitalismo, que pretende cristalizar como verdade que, para que um seja feliz, outro tenha que ser "eliminado". (T1)

No excerto (35), representado por possessivação, nos termos de Van Leeuwen (1997), o sistema capitalista é Ator de promessa e, implicitamente, Portador de uma pedagogia que tem por propósito seduzir as pessoas. Em (36), a nominalização do processo ("consolidação") encobre a agência do reality show, que repete e, assim, ajuda a cristalizar a ideia ensinada pelo capitalismo: a felicidade de um depende da exclusão do outro.

Nessa pedagogia, os "aprendizes" são os telespectadores, que aparecem ativados no contexto de interação com o reality show, mas passivados no contexto social mais amplo.

A ativação dos telespectadores ocorre quando exercem as funções de Ator, como em (37) e (38), e Experienciador, como em (39), (40), (41) e (42).

(37) [...] a Globo, junto com as companhias telefônicas, lucra rios de dinheiro com as ligações que as pessoas fazem para eliminar oS "irmãos". (T1)

(38) [...] vote, ligue, participe e compre. (T3)

(39) [...] 154 milhões de votos decidiram a final [...]. (T2)

(40) [...] um grupo concorda em ser visto por milhões de pessoas [...]. (T5)

(41) O público se sente cada vez mais poderoso com os reality shows. Basta um computador ou um celular para (o público) exercer o direito à interatividade e decidir os destinos dos participantes. (T2)

(42) Brincar de Deus, quem já não sonhou com isso? (T2)

Participando ativamente dos processos ligar e votar, em (37) e (38), os telespectadores experienciam uma função do jogo: decidir ora quem será "o churrasquinho da vez", ora quem será "entregue aos leões", ora quem "atuará como leão".

Na verdade, são convocados a isso, como evidencia o modo imperativo das orações em (39). A proposta "compre", nesse mesmo excerto, sinaliza a presença da pedagogia capitalista subjacente às ações aparentemente singelas de ligar e votar num dos brothers que estão no "paredão". Ao usar o telefone para esse fim, o telespectador está comprando o serviço prestado por uma empresa telefônica. Em outras palavras, não está agindo só como telespectador e participante do programa, mas como um consumidor, tal como ensina o sistema capitalista. 
Essa conduta é, indiretamente, estimulada quando os telespectadores são também ativados na posição de Experienciador dos processos de ver em (40), de sentir e de decidir em (41) e de sonhar em (42). Esses sentimentos e desejos que se materializam na ação de votar nos brothers são, de certa forma, a reação do público perante os apelos do apresentador do programa em (38).

Num contexto social mais amplo, contudo, os telespectadores aparecem representados por passivação, na função de Meta, como mostram os excertos a seguir:

(43) O Big Brother, assim, exerce esse papel de colocar sob os holofotes novas imagens que possam direcionar o comportamento dos jovens do País, (0) desviando-os de assuntos mais relevantes. (T4)

(44) [...] o que é que anda engravidando as gentes deste grande país [...]. (T1)

(45) [...] uma grande massa de brasileiros está encarcerada em uma política cruel [...]. (T4)

Nesses excertos, a população é afetada por processos que têm como agente, explícito, o Big Brother em (43) e, encoberto, o sistema capitalista em (44) e (45). Diante desses atores sociais que agem em conjunto, o povo é representando como impotente, uma vez que se encontra encarcerado em uma política que a voz autoral julga negativamente por meio do adjetivo "cruel" em (45).

Os telespectadores são, portanto, representados como aqueles que têm o poder de decidir o destino dos participantes do programa. Essa representação é ancorada ${ }^{6}$ na representação social do poder de Deus, a quem as religiões atribuem o poder de conduzir as vidas dos seres humanos. Por outro lado, esses mesmos telespectadores são afetados pelas ações das grandes emissoras de televisão e empresas patrocinadoras, que obtêm lucros e, ao mesmo tempo, direcionam comportamentos. Telespectadores brasileiros são, por conseguinte, representados, nos artigos de opinião analisados, como vítimas do sistema capitalista, assim como os brothers também o são.

\section{Considerações finais}

A descrição e a análise dos recursos léxico-gramaticais e semântico-discursivos propiciam um processo de leitura mais criterioso de textos. A verificação de quais atores sociais estão presentes no discurso, de como a linguagem é usada para representá-los e quais elementos sinalizam o posicionamento de quem os escreveu

Ancoragem, na teoria das Representações Sociais de Moscovici (2009), é o processo que aproxima aquilo que é estranho, perturbador, que não pode ser comunicado, a alguma categoria já existente, familiar. 
é parte importante do processo de compreensão de um texto, principalmente se este for dissertativo.

Para ilustrar esse processo, foram analisados recursos linguísticos utilizados em artigos de opinião que tratam de um mesmo assunto relacionado ao universo da mídia, publicados numa mesma fonte, no período de 2004 a 2011. Os atores sociais mais frequentes encontrados no discurso são o reality show, os participantes do programa, os telespectadores e o próprio articulista, referidos nos textos por meio de reiterações lexicais, formas pronominais anafóricas, elementos dêiticos, hiperônimos, hipônimos, nomeações, expressões metafóricas e elipse.

Os reality shows, com maior frequência de ocorrências no corpus analisado, são representados como um negócio lucrativo que tem emissoras de televisão e patrocinadores como os principais beneficiados. Entre os reality shows, aparece ativado o Big Brother Brasil, representado, na função de Ator, como uma ferramenta que se presta a três funções: dar visibilidade para pessoas que possam direcionar o comportamento dos jovens; beneficiar aproveitadores e despertar o voyeurismo nos telespectadores. Essas representações são avaliadas por meio de apreciações negativas, materializadas por uma série de Atributos constituintes de orações relacionais que estruturam definições para esse reality show no ponto de vista de alguns articulistas. Outros articulistas, porém, ao escolherem colocar o programa na função de Circunstância (e não de Ator), representam-no como um lugar onde seres humanos agem, expostos à contemplação por outros seres humanos. O reality show é representado, assim, como isento de responsabilidade sobre comportamentos antiéticos, pois é apenas um espaço onde esses comportamentos são praticados. Pode-se dizer que essas maneiras divergentes de representar os reality shows funcionam, nos termos de Scheufele (2000), como um mecanismo de retroalimentação de discussões na esfera pública.

Outros atores sociais frequentes no corpus são os participantes do reality show. Quando ativados, desempenhando as funções de Ator de processos concernentes ao jogo e de Experienciador de processos mentais desiderativos concernentes a objetivos que os levam a participarem do reality show, os participantes têm seus comportamentos julgados pela voz autoral. Por meio de recursos avaliativos de julgamento, são representados, de modo generalizado, como pessoas que se submetem a agir de forma antiética para conquistar dinheiro e poder.

Por outro lado, o uso de reciprocidade nas funções de Ator e Meta constrói uma dupla imagem para os participantes do programa no contexto da relação com os colegas de programa: algozes e vítimas. Na relação com os produtores do programa, porém, os participantes aparecem, na maioria das vezes, passivados, desempenhando funções de Receptor, Beneficiário e Meta de propostas verbalizadas pelos produtores ou pelo apresentador do programa. Nesse contexto, os brothers são defendidos pela voz autoral, o que se verifica pelo uso de marcas de 
afeto, julgamento e ironia, que avaliam negativamente as atitudes dos produtores do programa e também do sistema capitalista, que aparece como Ator de promessa e, implicitamente, Portador de uma pedagogia que tem por propósito seduzir as pessoas.

A vitimização dos participantes é, ainda, construída por meio de Atributos que sinalizam apreciação e metáforas lexicais que denotam intertextualidade com fatos históricos em que pessoas eram martirizadas sob o olhar curioso do povo. Desse modo, nos artigos de opinião analisados, as pessoas que se submetem a participar de um reality show aparecem representadas, principalmente, como vítimas - ora dos produtores do programa e da emissora de televisão, ora do sistema capitalista, cuja "pedagogia" as leva a desejarem coisas que só o dinheiro pode dar.

Com uma frequência de ocorrências muito próxima à dos participantes do programa, os telespectadores aparecem representados, no contexto do jogo, como aqueles que decidem o destino do jogador. O uso do modo imperativo nas propostas direcionadas pelo apresentador do programa ao público sinaliza que os telespectadores são conduzidos a "participarem" do jogo e, ao mesmo tempo, a utilizarem serviços de telecomunicação, comportando-se, assim como consumidores e atendendo à pedagogia do sistema capitalista. Num contexto social mais amplo, os telespectadores aparecem, na função de Meta, representados como impotentes diante uma política capitalista, que a voz autoral julga negativamente. Eles são, portanto, tão vítimas do sistema capitalista quanto os participantes dos reality shows.

Por fim, os articulistas são representados como pessoas bem informadas e observadoras da realidade, capazes de estabelecer relações por meio de operações analíticas e, assim, expressar opiniões que, divulgadas na mídia, passam a exercer um papel na formação da opinião pública. Essas representações estão manifestadas nos textos, principalmente, por meio de orações mentais cognitivas e emotivas, das quais os autores participam como Experienciador. O uso de recursos de Engajamento por expansão dialógica, expressos por modalizadores, abre o discurso para outras possibilidades de opinião. Dessa forma, os articulistas não impõem opiniões, mas estimulam a discussão a respeito do assunto.

Esses resultados, obtidos a partir da análise linguística de uma amostra de artigos de opinião disponibilizados no "Observatório da Imprensa", vão ao encontro da tese de Scheufele (2000) sobre o papel da mídia: alimentar a interação entre cidadãos mais informados e estimular a discussão sobre os mais diversos assuntos. Acrescenta-se, aqui, que um gênero textual que se presta muito bem à realização de tais discussões é o artigo de opinião. O estudo de um corpus de maior abrangência poderá evidenciar outros aspectos léxico-gramaticais e semântico-discursivos da linguagem usada para representar e avaliar atores 
sociais em contexto midiático. Dessa forma, podem-se desvelar mais detalhes para a compreensão de como se processa a formação de opinião, por meio de textos, na esfera pública.

FUZER, C. Victims and Villains on Reality Shows in Brazil: Representations and Evaluation Based on Lexicogrammar Evidences. Alfa, São Paulo, v.56, n.1, p.403-425, 2012.

- ABSTRACT: The aim of this study is to analyze the representations constructed in opinion articles published in Brazilian newspapers from the lexicogrammar and semanticdiscursive perspective. We have analyzed the lexicogrammar functions played by social actors selected from their recurrence in the corpus and evaluation marks to the representations identified. For this, we used the Systemic Functional Linguistics theory, focusing on categories of transitivity system by Halliday \& Matthiessen (2004), forms of representation of social actors by van Leeuwen (1997) and the Appraisal by Martin \& White (2005). The results show that the social actors that are most frequently present in the discourse are the opinion article writers, the reality show, the participants of the program and the audience. They appear sometimes activated, sometimes passivated, depending on the linguistic context to which they relate. The presence of linguistic traces of trial judgment and appreciation, often accompanied by gradation, indicates the negative valuations for the reality shows and their agents, while the use of marks of affection signals a defense of participants by the authorial voice. Like the participants of the program, the Brazilian audience is represented as a victim of the current Capitalist system, which is present in the dynamics of reality shows.

- KEYWORDS: Systemic functional grammar. Transitivity. Representation. Evaluation. Context. Media.

\section{REFERÊNCIAS}

ALMEIDA, F. S. D. P. Avaliação na linguagem: os elementos de atitude no discurso do professor: um exercício em análise do discurso sistêmico-funcional. São Carlos: Pedro \& João Editores, 2010.

CABRAL, S. R. S. A mídia e o presidente: um julgamento com base na teoria da valoração. 2007. 248 f. Tese (Doutorado em Letras) - Universidade Federal de Santa Maria, Santa Maria, 2007.

DRYZEK, J. S. Legitimidade e economia na democracia deliberativa. In: COELHO, V. S. P.; NOBRE, M. (Org.). Participação e deliberação: teoria democrática e experiências institucionais no Brasil contemporâneo. São Paulo: 34, 2004.

FERREIRA, C. Longevidade do Big Brother Brasil espanta até os mais otimistas. Correio Braziliense, Brasília, 11 jan. 2011. Disponível em: <http://www. observatoriodaimprensa.com.br/artigos.asp?cod=625TVQ003>. Acesso em: 20 mar. 2011. 
FUZER, C. Formas de representação de atores sociais no contexto jurídico penal. The ESPecialist, São Paulo, v.31, n.1, p.21-48, 2010.

FUZER, C.; CABRAL, S. R. S. Introdução à gramática sistêmico-funcional em língua portuguesa. Santa Maria: UFSM, 2010. Caderno Didático.

HALLIDAY, M. A. K. On grammar. Edited by Jonathan J. Webster. London: Continuum, 2002. Collected Works of M.A.K. Halliday.

HALLIDAY, M. A. K.; HASAN, R. Language, context, and text: aspects of language in a social-semiotic perspective. Oxford: Oxford University Press, 1989.

HALLIDAY, M. A. K.; MATTHIESSEN, C. An introduction to functional grammar. 3.ed. London: Arnold, 2004.

. Construing experience through meaning: a language-based approach to cognition. London: Continuum, 1999.

. Systemic functional grammar: a first step into the theory. 1997. Disponível em: <http://www.alvinleong.info/sfg/sfgintro.html>. Acesso em: 21 mar. 2011. HOUAISS, A. Dicionário eletrônico Houaiss. 3.ed. Rio de Janeiro: Objetiva, 2009. LIMA, S.; CORÔA, M. L. M. S. Configuração e papel do sistema de avaliatividade no gênero reportagem. Calidoscópio, São Leopoldo, v. 8, n.2, p.127-137, maio-ago. 2010.

MARTIN, J.; ROSE, D. Working with discourse: meaning beyond the clause. New York: Continuum, 2003.

MARTIN, J. R.; WHITE, P. The language of evaluation: appraisal in English. New York: Palgrave, 2005.

MATTA, R. O Brasil do "Big Brother". Observatório da Imprensa, São Paulo, ano16, n.175, 24 fev. 2004. Disponível em: <http://www.observatoriodaimprensa.com.br/ artigos.asp?cod=265ASP022> . Acesso em: 20 mar. 2011.

MOSCOVICI, S. Representações sociais: investigações em psicologia social. Tradução de Pedrinho A. Guareschi. 6.ed. Petrópolis: Vozes, 2009.

OLIVEIRA, A. Pão, circo e BBB. Observatório da Imprensa, São Paulo, ano16, n.715, 03 abr. 2006. Disponível em: <http://www.observatoriodaimprensa.com.br/artigos. asp?cod=375TVQ003> . Acesso em: 20 mar. 2011.

PIMENTA, L. M. A formação da opinião pública e as inter-relações com a mídia e o sistema político. In: CONGRESSOS DA ASSOCIAÇÃO BRASILEIRA DE PESQUISADORES EM COMUNICAÇÃO E POLÍTICA, 2, dez. 2007, Belo Horizonte. Anais... Belo Horizonte: Compolítica, 2007. Disponível em: <http:// www.compolitica.org/home/wp-content/uploads/2011/01/sc_jp-lidiane.pdf>. Acesso em: 22 mar. 2011. 
SCHEUFELE, D. A. Talk or conversation? dimensions of interpersonal discussion and their implications for participatory democracy. Journalism and MasS Communication Quarterly, [S.1.], v.77, n.4, p.727-743, jan. 2000.

SCOTT, M. WordSmith Tools. Disponível em: <http://www.lexically.net/ wordsmith>. Acesso em: 25 mar. 2011.

TAVARES, E. A pedagogia do grande irmão platinado. Diário do Noroeste, Paranavaí, 27 jan. 2011. Opinião, p. 2. Disponível em: <http://www.observatoriodaimprensa. com.br/artigos.asp?cod=627TVQ001>. Acesso em: 20 mar. 2011.

TERRA, R. O corifeu do Big Brother Brasil. Observatório da Imprensa, São Paulo, ano16, n.175, 03 mar. 2009. Disponível em: <http://www.observatoriodaimprensa. com.br/artigos.asp?cod=527TVQ002 >. Acesso em: 20 mar. 2011.

VAN LEEUWEN, T. A representação dos actores sociais. In: PEDRO, E. R. (Org.). Análise crítica do discurso. Lisboa: Caminho, 1997.

VIAN JR., O.; SOUZA, A. A.; ALMEIDA, F. S. D. (Org.). A linguagem da avaliação em língua portuguesa: estudos sistêmico-funcionais com base no sistema de avaliatividade. São Carlos: Pedro \& João, 2010.

VIAN JR., O. O sistema de avaliatividade e os recursos para gradação em língua portuguesa: questões terminológicas e de instanciação. DELTA, São Paulo, v.25, n.1, p.99-129, 2009.

WHITE, P. R. R. Valoração - a linguagem da avaliação e da perspectiva. Linguagem em (Dis)curso, Tubarão, v.4, n.esp., p.178-205, 2004.

Recebido em 10 de setembro de 2011.

Aprovado em 20 de agosto de 2012. 
